\title{
DESKRIPSI I-JOGJA SEBAGAI MODEL BARU PERPUSTAKAAN DIGITAL DI YOGYAKARTA
}

\author{
Heri Abi Burachman Hakim ${ }^{1 *}$, Bandono ${ }^{2}$, and Hari Pranoto ${ }^{3}$ \\ ${ }^{123}$ Institut Seni Indonesia Yogyakarta \\ UPT Perpustakaan Institut Seni Indonesia Yogyakarta \\ Badan Perpustakaan dan Arsip Daerah, Daerah Istimewa Yogyakarta \\ *Correspondence: hakimdaffa43@gmail.com
}

\begin{abstract}
Libraries in Indonesia are starting to compete in developing digital libraries. College, public, and regional libraries have started to develop digital libraries. The development of digital libraries is based on the consideration of providing opportunities for greater access to collections owned by libraries and adjusting the format of library services with the characteristics of users who are familiar with information technology products. Seeing the importance of digital libraries, BPAD DIY began to develop a digital library under the name I-Jogja. I-Jogja is a digital library portal developed in the Android and iOs operating systems. I-Jogja was developed using the iLibrary software created by PT. Woolu Maya script. I-Jogja offers a new concept in digital library management, where to access public collections, people do not need to download but borrow collections from the digital library portal. This digital collection lending concept is known as e-lending. Through research, the researcher aims to describe the management of I-Jogja as a new concept of digital library management. Research that researchers conducted using qualitative research methods. From this research, it is found that the text-based I-Jogja collection, to access I-Jogja must be registered in the application, functions as a means of fostering reading interest, policies related to membership and access patterns, is able to be a means of fostering reading interest, able to run on the operating system Android and iOS.
\end{abstract}

\begin{abstract}
ABSTRAK
Perpustakaan di Indonesia mulai berlomba-lomba mengembangkan perpustakaan digital. Perpustakaan perguruan tinggi, perpustakaan umum dan perpustakaan daerah mulai mengembangkan perpustakaan digital. Pengembangan perpustakaan digital ini didasarkan pertimbangan untuk memberikan peluang akses yang lebih besar terhadap koleksi yang dimiliki perpustakaan dan penyesuaian format layanan perpustakaan dengan karakteristik pemustaka yang familiar menggunakan produk teknologi informasi. Melihat pentingnya perpustakaan digital, maka BPAD DIY mulai mengembangkan perpustakaan digital dengan nama I-Jogja. I-Jogja merupakan portal perpustakaan digital yang dikembangkan dalam sistem operasi Android dan iOS. I-Jogja dikembangkan dengan perangkat lunak iLibrary karya PT. Woolu Aksara Maya. I-Jogja menawarkan konsep baru dalam pengelolaan perpustakaan digital, dimana untuk mengakses koleksi masyarakat tidak perlu mengunduh tetapi meminjam koleksi di dalam portal perpustakaan digital. Konsep peminjaman koleksi digital ini dikenal dengan istilah e-lending. Melalui penelitian, peneliti bertujuan untuk mendeskripsikan pengelolaan I-Jogja sebagai konsep baru pengelolaan perpustakaan digital. Penelitian yang peneliti lakukan menggunakan metode penelitian kualitatif. Dari penelitian ini diperoleh hasil bahwa koleksi I-Jogja berbasis teks, untuk mengakses I-Jogja harus terdaftar di dalam aplikasi, berfungsi sebagai sarana pembinaan minat baca, kebijakan terkait keanggotaan dan pola akses, mampu menjadi sarana pembinaan minat baca, mampu berjalan di sistem operasi Android dan iOS.
\end{abstract}

Keywords: Digital Library; E-Lending; E-Book.

\section{PENDAHULUAN}

\subsection{Latar Belakang}

Perpustakaan selalu berusaha melakukan penyesuaian dengan karateristik dan keinginan pemustaka. Perpustakaan mulai memanfaatkan produk-produk teknologi informasi ketika masyarakat mulai bergantung pada produk-produk teknologi informasi. Otomasi perpustakaan dan pengembangan perpustakaan digital merupakan ilustrasi dari pemanfaatan teknologi informasi dalam pengelolaan perpustakaan. 
Saat ini ketika masyarakat mulai akrab dengan perangkat mobile technology sepert smartphone, perpustakaan mulai mengembangkan aplikasi mobile. Banyak perpustakaan di tanah air mulai mengembangkan OPAC versi mobile yang memungkinkan masyarakat mengakses OPAC melalui smartphone yang dimiliki. Pengembangan OPAC versi mobile ini merupakan usaha penyesuaian layanan perpustakaan dengan karateristik pemustaka yang terbiasa mengakses informasi melalui smartphone.

Sebagai upaya penyesuaian terhadap mayoritas karateristik pemustaka, Badan Perpustakaan dan Arsip Daerah Istimewa Yogyakarta membangun I-Jogja. I-Jogja merupakan portal perpustakaan digital yang dapat diakses melalui smartphone atau komputer. Melalui smartphone dan komputer yang dimiliki masyarakat dapat mengakses berbagai buku yang dihasilkan penerbit nasional, penerbit lokal dan publikasi yang dihasilkan oleh Pemerintah Provinsi Daerah Istimewa Yogyakarta. Dengan konsep perpustakaan digital I-Jogja diharapkan mampu mendekatkan koleksi kepada masyarakat serta meningkatkan akses masyarakat terhadap koleksi yang telah dimiliki perpustakaan.

I-Jogja merupakan perpustakaan digital yang memiliki perbedaan konsep dengan pengelolaan perpustakaan digital pada umumnya di Indonesia. Konsep perpustakaan digital di Indonesia pada umumnya menyajikan koleksi digital dengan cara diunduh oleh pemustaka. Setelah proses mengunduh, maka pemustaka dapat mengakses informasi yang terekam dalam koleksi digital tersebut. Berbeda dengan I-Jogja, perpustakaan digital ini memiliki konsep akses yang berbeda, pemustaka diminta untuk masuk kedalam aplikasi I-Jogja dan selanjutnya meminjam e-book atau koleksi digital lainnya yang tersedia di dalam I-Jogja. Dengan kata lain I-Jogja menggunakan konsep e-lending atau peminjaman elektronik dalam proses akses koleksi digital yang dimiliki oleh BPAD DIY.

Sebagai konsep baru dalam pengelolaan perpustakaan digital, penulis merasa perlu untuk mendeskripsikan bagaimana konsep baru pengelolaan perpustakaan digital. Atas dasar ini, maka rumusan masalah dalam penelitian ini adalah bagaimana model perpustakaan digital yang digunakan dalam pengembangan I-Jogja sebagai portal perpustakaan digital? Dengan menggunakan teori model perpustakaan digital, penulis mencoba mendeskripsikan konsep baru perpustakaan digital dalam pengembangan I-Jogja. Dengan deskripsi ini, diharapkan mampu memberikan gambaran konsep sehingga dapat membantu pimpinan perpustakaan dan pustakawan untuk mengadopsi konsep baru perpustakaan digital ini atau tidak.

\subsection{Definisi Perpustakaan Digital}

Di awal pembahasan ini penulis merasa perlu untuk memberikan definisi tentang perpustakaan digital. Melalui definisi ini penulis berharap mampu membangun persepsi yang sama tentang perpustakaan digital karena banyak tokoh yang mengatakan definisi yang berbeda tentang perpustakaan.

Definisi pertama tentang perpustakaan digital dikemukan oleh Leiner (1998), menurut beliau perpustakaan digital adalah serangkaian layanan dan kumpulan objek informasi yang mendukung pengguna dalam berurusan dengan objek informasi yang tersedia secara langsung atau tidak langsung melalui sarana elektronik atau digital (Seadle \& Greifeneder, 2007). Definisi ini mengisyaratkan bahwa perpustakaan digital terkait dengan layanan objek digital yang dilakukan secara langsung maupun tidak langsung.

Definisi kedua disampaikan oleh Brogman (2000), menurut Brogman perpustakaan digital merupakan kombinasi dari layanan, arsitektur, serangkaian sumber informasi, database berbasis teks, angka, grafik, 
suara, video dan seperangkat alat yang mampu menghimpun, menelusur dan memanfaatkan sumber informasi sehingga tersedia (Chowdury, 2003). Definisi yang disampaikan Brogman tidak hanya sebatas melayankan objek digital secara langsung maupun tidak langsung, perpustakaan digital juga menyangkut aktivitas menghimpun, menelusur memanfaatkan sumber informasi.

Definisi lain dikemukakan oleh American Digital Library Federation, menurut organisasi ini perpustakaan digital adalah organisasi yang menyediakan sumber daya, termasuk staf khusus, untuk memilih, struktur, menawarkan akses intelektual, menafsirkan, mendistribusikan, menjaga integritas, dan memastikan kegigihan dari waktu ke waktu pengumpulan karya digital sehingga mereka tersedia secara ekonomis untuk digunakan oleh komunitas atau kelompok komunitas tertentu (Cleveland, 2008). Definisi terakhir ini lebih kompleks dibandingkan definisi-definisi sebelumnya, definisi yang menurut American Digital Library Federation ini melihat perpustakaan digital sebagai sebuah organisasi yang didalamnya terdapat berbagai sumber daya untuk mengumpulkan karya digital sehingga dapat diakses oleh masyarakat secara ekonomis. Kata ekonomis inilah yang membedakan antara perpustakaan digital dengan database atau jurnal online, dimana perpustakaan digital memungkinkan mengakses karya atau informasi digital secara gratis atau lebih ekonomis.

Berdasarkan ketiga pendapat di atas, menurut penulis, perpustakaan digital adalah pemanfaatkan sumber daya manusia, perangkat keras dan lunak dalam rangka mengakuisisi, organisasi, mendistribusikan dan menjaga integritas informasi atau koleksi digital sehingga dapat diakses oleh masyarakat dari waktu ke waktu.

\subsection{Teori Model Perpustakaan Digital}

Saat ini ada dua teori model perpustakaan digital yang populer digunakan untuk mengkaji model perpustakaan digital. Kedua teori tersebut familiar digunakan sebagai teori untuk melakukan kajian terkait perpustakaan digital. Teori model tersebut adalah teori referensi DELOS dan 5S Teori, berikut ini penjelasan tentang kedua teori tersebut:

\section{Teori Model Referensi DELOS}

Dalam teori ini model perpustakaan digital akan ditinjau dari 6 komponen yaitu konten, pengguna, fungsionalitas, kebijakan, kualitas dan arsitektur (Isah, Mutshewa, Serema, \& Kenosi, 2013). Penjelasan terkait komponen-komponen tersebut, disajikan di bawah ini:

a. Konten

Komponen utama pada teori ini adalah konten. Konten merepresentasikan informasi yang dikelola dalam perpustakaan digital. Konsep umum dalam bahasan tentang konten terkait objek informasi yang didalamnya terdapat dokumen berbasis teks, gambar, suara, multimedia, objek 3 dimensi, games, virtual reality, data set dan databases.

b. Pengguna

Pengguna merepresentasikan sumber daya manusia yang berinteraksi dengan sistem. Perpustakaan digital mempertemukan pengguna dengan konten informasi yang berusaha mempertemukan kebutuhan informasi pengguna dengan konten informasi perpustakaan digital.

c. Fungsionalitas

Fungsionalitas memiliki makna bahwa fasilitas yang dimiliki mampu mendukung tujuan layanan dari perpustakaan digital kepada pemustaka. Fungsionalitas mencerminkan bahwa fungsi sistem merupakan perwakilan dari kebutuhan komunitas pengguna perpustakaan. 
d. Kebijakan

Kebijakan mewakili aturan dan ketentuan, termasuk hak digital, yang mengatur pengoperasian elemen-elemen dari perpustakaan digital. Aturan atau ketentuan tersebut seperti kebijakan menentukan perilaku pengguna yang dapat diterima, manajemen hak digital, privasi, dan sebagainya.

e. Kualitas

Komponen kualitas mewakili aspek kualitas dan fungsionalitas dari sistem perpustakaan digital yang digunakan. Apakah sistem tersebut telah menjalankan fungsinya dengan baik?

f. Arsitektur

Komponen arsitektur mencerminkan perangkat lunak dan perangkat keras yang dibutuhkan dalam mewujudkan perpustakaan digital.

2. Teori $5 \mathrm{~S}$

Teori lain yang digunakan untuk mengkaji model perpustakaan digital adalah teori 5S. Teori 5S dikembangkan dalam rangkat menyatukan antara teori dan praktik dalam perpustakaan digital (Isah et al., 2013). Teori ini mendefinisikan perpustakaan digital ke dalam 5 komponen (Zhu, 2002), yaitu:

a. Alur

Komponen pertama ini akan menggambarkan bagaimana alur penyelesaian masalah komunikasi dengan pemustaka.

b. Struktur

Komponen struktur terkait dengan bagaimana organisasi informasi dilakukan dalam pengelolaan perpustakaan digital.

c. Ruang

Komponen ruang akan merepresentasikan bagaimana menangani masalah penyajian informasi dengan cara yang bermanfaat.

d. Skenario

Komponen skenario menggambarkan bagaimana menangani masalah mengkomunikasikan informasi kepada pengguna.

e. Masyarakat

Komponen masyarakat akan menggambarkan bagaimana perpustakaan digital mampu memenuhi kebutuhan informasi dari pemustaka yang berbeda.

Dalam kajian ini, penulis akan menggunakan Teori Model Referensi DELOS untuk mendeskripsikan bagaimana konsep aplikasi e-lending dalam layanan I-Jogja. Dengan kajian ini diharapkan mampu memberikan alternatif terkait pengembangan perpustakaan digital dan institutional repository di Indonesia. Pengembangan perpustakaan digital yang lebih memperhatikan hak cipta dan hak ekonomi yang melekat pada koleksi digital.

\subsection{Deskripsi I-Jogja}

I-Jogja merupakan portal perpustakaan digital yang dimiliki BPAD Daerah Istimewa Yogyakarta. Portal ini memberikan layanan peminjaman e-book dan publikasi digital yang dihasilkan oleh berbagai instansi pemerintah dibawah Pemerintahan Provinsi Daerah Istimewa Yogyakarta. Layanan perpustakaan ini disediakan secara gratis kepada masyarakat Yogyakarta.

I-Jogja merupakan perpustakaan digital yang dikembangkan dengan menggunakan aplikasi iLibrary. iLibrary merupakan Aplikasi perpustakaan digital berbasis media sosial yang dikembangkan untuk 
memberdayakan masyarakat dan meningkatkan minat baca dilengkapi dengan beragam fitur untuk mendapatkan pengalaman baru membaca yang lebih mudah dan menyenangkan dimana saja dan kapan saja. iLibrary ini juga digunakan untuk membangun perpustakaan digital sejenis seperti I-Jakarta, ITani, I-Pusnas dan I-Jateng. Aplikasi ini dikembangkan oleh PT. Woolu Akasara Maya yang berkantor di Jakarta dan Yogyakarta.

Perpustakaan digital ini dapat diakses dengan menggunakan smartphone atau handphone berbasis Android dan iOS. Pengembangan akhir dari perpustakaan digital ini tersedianya paket instalasi yang memungkinkan perpustakaan digital ini diinstalasi di laptop atau personal komputer. Dengan demikian perpustakaan digital ini dapat diakses dengan menggunakan perangkat teknologi informasi yang sering digunakan masyarakat saat ini seperti smartphone dan laptop.

Konsep perpustakaan digital yang dikembangkan dalam I-jogja berbeda dengan sistem perpustakaan digital pada umumnya. Konsep layanan perpustakaan digital di Indonesia didominasi oleh konsep unduh, kemudian membaca file koleksi digital yang telah diunduh. Konsep layanan dalam I-Jogja adalah mengunduh, meminjam dan membaca koleksi digital yang telah dipinjam. Pemustaka akan meminjam koleksi tersebut selama satu minggu melalui halaman user khusus pemustaka. Apabila telah satu minggu koleksi digital tersebut akan dikembalikan dan tidak dapat diakses oleh pemustaka.

Konsep peminjaman seperti ini dikenal dengan istilah e-lending atau electronic lending. E-lending merupakan salah satu bentuk penghargaan hak cipta dalam pemanfaatan koleksi digital. Konsep layanan koleksi digital dengan cara mengunduh terkadang mengabaikan hak cipta dari koleksi digital atau lisensi pemanfaatan koleksi digital tersebut. Hak cipta terkait pemanfaatan koleksi digital dikelola dengan konsep Digital Right Management (DRM). DRM dapat dimaknai sebagai kerangka kerja yang melindungi dan mengelola hak penggunaan dan logika bisnis dari konten digital atau koleksi digital (Bohner, 2008). Konsep DRM ini akan melindungi hubungan antara penulis, penerbit dan perpustakaan dalam konteks layanan koleksi digital.

Dengan implementasi e-lending dalam pengelolaan perpustakaan digital akan melindungi hak cipta dan hak ekonomi dari penulis. Dengan konsep ini maka penulis akan semakin termotivasi untuk menghasilkan karya dalam bentuk tulisan. Hak cipta dan hak ekonomi dari koleksi digital ini sering terlupakan dalam pengelolaan koleksi digital, e-book dan e-journal dan databases. Konsep e-lending ini juga akan melindungi perpustakaan dan pustaka dari pelanggaran hak cipta.

E-lending merupakan bentuk penghargaan hak cipta kepada penulis e-book atau konten digital lainnya. Pemustaka tetap dapat mengakses informasi secara lengkap tanpa mengesampingkan hak cipta dari penulis. Dengan demikian hak mendapatkan informasi dari pemustaka dapat terpenuhi tanpa mengesampingkan hak cipta dan hak ekonomi yang dimiliki penulis atau penerbit.

Konsep e-lending dalam pengelolaan materi atau koleksi digital serta perpustakaan digital yang mengandalkan smartphone atau perangkat mobile untuk mengakses merupakan konsep baru dalam pengelolaan perpustakaan digital di tanah air. Untuk itu penulis tergerak mengkaji bagiamana konsep baru pengelolaan perpustakaan digital ini. 


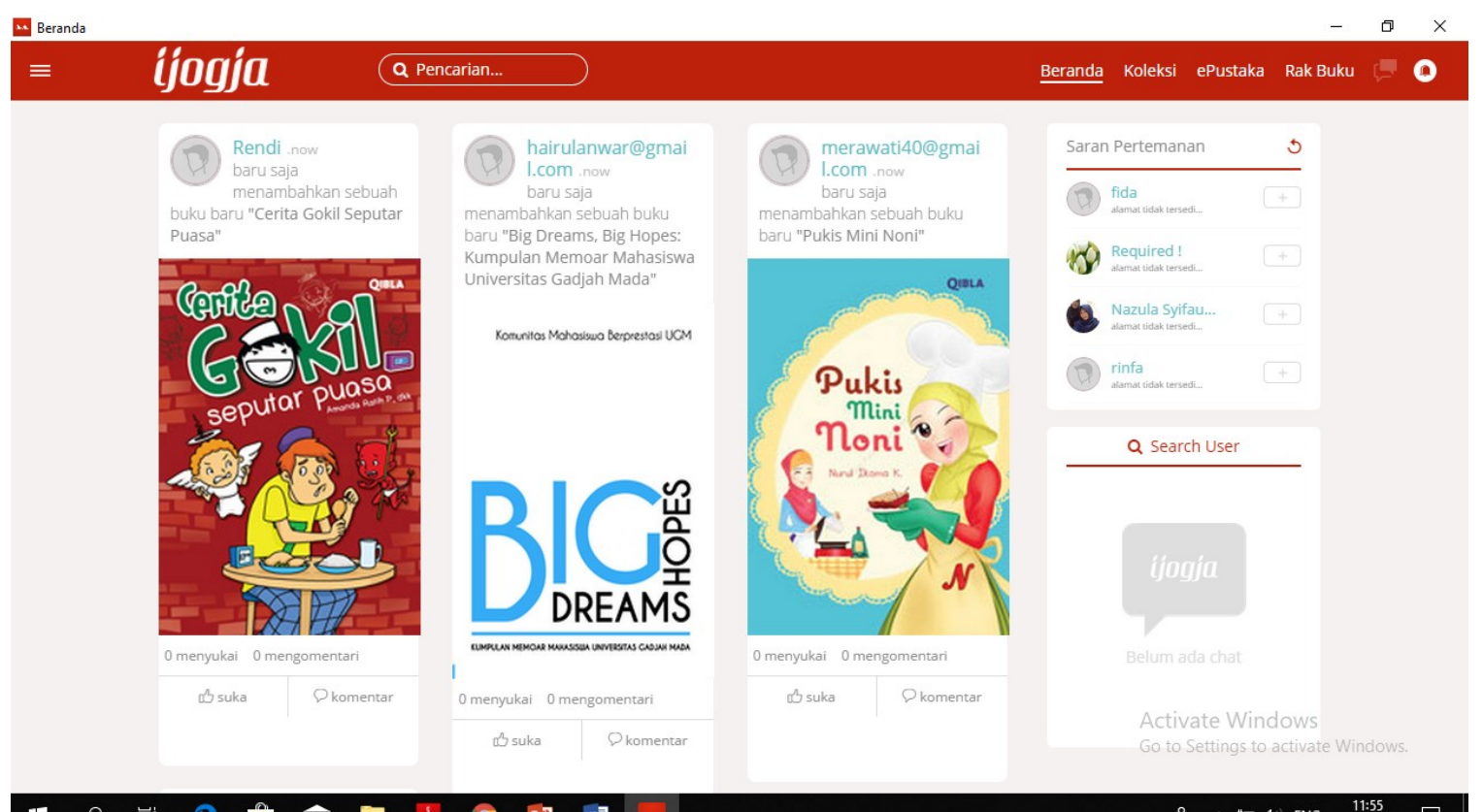

* 0 品

Gambar 1. Halaman Depan I-Jogja

\section{METODE}

Pada penulisan artikel berjudul "Deskripsi I-Jogja sebagai Model Baru Perpustakaan Digital di Yogyakarta" ini penulis menggunakan metode kualitatif. Menurut Bogdan dan Taylor (1975), kualitatif merupakan metode yang pada gilirannya menghasilkan data deskriptif dalam bentuk kata baik tertulis maupun lisan (Ratna, 2016). Dalam kajian ini peneliti mengumpulkan data dengan menggunakan teknik wawancara, observasi, dan dokumen. Wawancara dalam penelitian kualitatif dilakukan secara purposive, yaitu memilih informan penelitian dengan pertimbangan tertentu (Sugiono, 2012). Informan yang dipilih adalah staf perpustakaan yang memahami operasional I-Jogja sehingga mampu memberikan gambaran yang jelas tentang I-Jogja. Penulis juga melakukan observasi terhadap I-Jogja dan berbagai dokumen atau manual dari I-Jogja. Setelah data terkumpul dengan menggunakan berbagai teknik tersebut, data selanjutnya dianalisa dengan menggunakan pendekatan kualitatif.

\section{HASIL DAN PEMBAHASAN}

E-lending dalam pengelolaan perpustakaan digital seperti I-Jogja merupakan konsep baru dalam pengelolaan perpustakaan digital di Yogyakarta. Perpustakaan digital di Yogyakarta didominasi oleh perpustakaan digital atau institutional repository yang melayankan koleksinya dengan cara mengunduh kemudian membaca koleksi tersebut. Konsep ini berbeda dengan konsep perpustakaan digital yang dikembangkan dalam I-Jogja, pemustaka dipaksa untuk menguduh file, meminjam koleksi digital dan membacanya. Konsep baru perpustakaan digital ini sangat menghargai hak cipta dan hak ekonomi yang melekat pada penulis dan penerbit. Penghargaan atas hak cipta dan ekonomi ini akan memotivasi penulis untuk memproduksi konten digital.

Kajian yang dilakukan bertujuan untuk mengetahui bagaimana model perpustakaan digital yang digunakan dalam pengembangan I-Jogja sebagai portal perpustakaan digital. Dengan kajian ini, diharapkan mampu mendeskripikan model perpustakaan yang digunakan. Untuk mengetahui model yang digunakan maka penulis menggunakan Teori Referensi Model DELOS. Penggunaan teori tersebut didasarkan pertimbangan bahwa Teori Referensi Model DELOS merupakan cikal bakal dari berbagai teori model perpustakaan digital. Berikut ini hasil analisis penulis: 


\section{Konten}

Dalam teori ini komponen pertama yang digunakan untuk menganalisa model perpustakaan digital adalah konten dari perpustakaan digital. Konten merepresentasikan informasi yang dikelola dalam perpustakaan digital. Informasi yang dikelola perpustakaan digital terdiri dari berbagai dokumen berbasis teks, gambar, suara, multimedia, objek 3 dimensi, games, virtual reality, data set dan database (Isah et al., 2013). Informasi tersebut diperlukan masyarakat dalam rangkat mendukung aktivitas hariannya.

Konten dari I-Jogja adalah buku elektronik (e-book) dan koleksi digital lainnya yang tersimpan dalam format PDF. PDF atau Portable Document Format merupakan salah satu format dokumen digital berbasis teks yang populer digunakan untuk buku dan artikel dalam format digital (Chowdhury, 2003). Keunggulan dokumen ini adalah minimnya potensi untuk dimanipulasi sehingga menjaga orisinalitas koleksi digital. PDF juga memungkinkan menyimpan gambar, grafik dan bagan didalam koleksi digital tanpa menurunkan kualitas gambar tersebut. Ukuran file PDF juga cukup kecil ketika file tersebut disajikan melalui internet (Chowdhury, 2003).

Koleksi e-book yang tersimpan dalam format FDF, merupakan buku dari berbagai penerbit yang telah menjadi rekan kerja PT. Woolu Aksara Maya sebagai pengembang I-Jogja. E-book tersebut dapat dipinjam dengan menggunakan aplikasi I-Jogja secara gratis. Aplikasi tersebut dapat diakses dengan menggunakan computer desktop atau perangkat mobile yang dimiliki oleh masyarakat. Akses konten digital dengan menggunakan perangkat mobile yang dimiliki perpustakaan merupakan bentuk penyesuaian perpustakaan terhadap pemustaka milenial. Pemustaka milenial saat ini mendominasi pengguna perpustakaan dan mereka sangat familiar memanfaatkan perangkat mobile untuk mengakses informasi.

I-Jogja belum menghimpun koleksi digital dalam format gambar, suara, multimedia, objek 3 dimensi, games, virtual reality, data set dan database. I-Jogja perlu melengkapi ragam koleksi digital yang dikelola dengan ragam koleksi digital tersebut. Varian dari koleksi digital yang dikelola akan memotivasi pemustaka untuk mengakses I-Jogja.

2. Pengguna

Komponen pengguna berusaha untuk menggambarkan bagaimana perpustakaan digital mampu memenuhi kebutuhan informasi pemustaka yang beragam. Pengguna I-Jogja merupakan pemustaka yang telah terdaftar didalam aplikasi I-Jogja. Pemustaka tersebut dapat berasal dari Yogyakarta maupun luar Yogyakarta. Untuk terdaftar sebagai anggota masyarakat dapat mendaftarkan diri dengan menggunakan email melalui faslitas pendaftaran yang ada didalam aplikasi atau menggunakan username dan password Facebook untuk masuk ke dalam aplikasi.

Pemustaka melakukan registrasi ke dalam I-Jogja dengan tujuan dapat mengakses koleksi digital yang tersimpan di dalam perpustakaan digital tersebut. Usaha ini dilakukan dalam rangka memenuhi kebutuhan informasi pemustaka. Dengan mengakses koleksi digital yang terhimpun di dalam I-Jogja diharapkan mampu memenuhi kebutuhan informasi pemustaka.

Untuk dapat memenuhi kebutuhan informasi pemustaka, perpustakaan perlu mengadakan survei terkait kebutuhan e-book dan informasi pemustaka, akan tetapi I-Jogja tidak menyediakan 
fasilitas untuk memberikan usulan pengadaan e-book. Untuk itu perlu diberikan fasilitas usulan pengadaan e-book sehingga koleksi yang dihimpun dalam I-Jogja mampu memenuhi kebutuhan informasi pemustaka. Dengan semakin mendekati kebutuhan informasi masyarakat maka akan memotivasi masyarakat untuk mengakses I-Jogja.

3. Fungsionalitas

Fungsionalitas memiliki makna bahwa fasilitas yang dimiliki mampu mendukung tujuan layanan dari perpustakaan digital kepada pemustaka. Fungsionalitas mencerminkan bahwa fungsi sistem merupakan perwakilan dari kebutuhan komunitas pengguna perpustakaan.

Tujuan dari I-Jogja adalah meningkatkan minat baca dengan menggunakan perpustakaan digital berbasis media sosial. Apabila melihat tujuan dan fasilitas yang disediakan, menurut penulis semua fasilitas yang disediakan I-Jogja mampu berjalan dengan sempurna dalam rangka meningkatkan minat baca masyarakat.

Saat ini sistem yang dikembangkan belum mewakili kebutuhan pemustaka. Pemustaka diberikan fasilitas untuk meminjam koleksi digital, memberikan penilaian terhadap koleksi digital dan sharing koleksi digital. Akan tetapi, fasilitas yang memungkinkan pemustaka memberikan masukan terkait koleksi dan pengembangan sistem belum tersedia.

Pengembang perlu berfikir memberikan fasilitas yang memungkinkan pemustaka memberikan masukan terkait koleksi yang dibutuhkan pemustaka. Fasilitas ini sangat diperlukan oleh pemustaka sehingga kebutuhan informasi pemustaka dapat terpenuhi. I-Jogja akan dipenuhi oleh koleksi yang dibutuhkan oleh pemustaka. Koleksi yang memenuhi kebutuhan pemustaka akan memotivasi masyarakat mengakses I-Jogja.

4. Kebijakan

Komponen kebijakan mewakili aturan dan ketentuan, termasuk hak digital, yang mengatur pengoperasian elemen-elemen dari perpustakaan digital. Dengan aturan dan ketentuan tersebut diharapkan terciptanya keteraturan dalam pemanfaatkan koleksi digital dan menghargai hakhak dari stakeholder perpustakaan digital.

Dalam pengelolaan ada beberapa peraturan diantaranya terkait keanggotaan. Keanggotaan IJogja terbuka bagi masyarakat umum dan tidak dibatasi pada area Yogyakarta. Buku dalam format elektronik memberikan peluang buku tersebut diakses secara kolektif. Atas dasar inilah pengguna I-Jogja tidak hanya dibatasi bagi masyarakat Yogyakarta.

Untuk mendaftar masyarakat dapat mendaftar melalui formulir yang disediakan oleh aplikasi. Masyarakat juga dapat mengakses I-Jogja tanpa perlu mendaftar dengan menggunakan username dan password Facebook. Konsep pemanfaatan username dan password Facebook ini semakin memberikan kesempatan yang luas kepada masyarakat untuk mengakses e-book yang ada di dalam I-Jogja.

Peraturan lainnya terkait akses koleksi digital adalah koleksi digital diakses dengan cara mengunduh dan kemudian meminjamkannya dengan masa pinjam 7 hari. Pemustaka dapat membaca e-book atau koleksi digital selama 7 hari dan dapat kembali memperpanjang peminjaman selama 7 hari kedepan. Apabila masa peminjaman telah selesai maka e-book 
tersebut tidak dapat diakses kembali oleh pemustaka dan apabila pemustaka ingin meminjam, harus melakukan peminjaman ulang.

I-Jogja mengaplikasikan e-lending dalam melayankan koleksinya kepada masyarakat. Elending atau peminjaman elektronik merupakan desain layanan untuk peminjaman buku elektronik. Konsep e-lending ini merupakan penghormatan terhadap hak digital dari penulis dan penerbit. Dengan konsep ini pemustaka dapat mengakses informasi secara full text tanpa harus mengunduh file. Konsep mengunduh file memungkinkan pemustaka mencetak dan mendistribusikan ulang file. Kemudahan masyarakat dalam mencetak dan mengunduh file dapat mempengaruhi penulis menghasilkan publikasi ilmiah dalam format digital.

Mencetak dan mendistribusikan ulang file ini merupakan salah satu bentuk pelanggaran hak digital. Dengan konsep e-lending ini, pemustaka dan pustakawan akan terhindar dari pelanggaran hak digital atau hak cipta. Penghargaan terhadap hak cipta buku elektronik akan memotivasi penulis dan penerbit untuk menghasilkan buku elektronik atau materi digital lainnya. Penghargaan hak cipta tersebut juga memiliki makna penghargaan hak ekonomi yang melekat pada buku elektronik yang dihasilkan.

5. Kualitas

Komponen kualitas mewakili aspek kualitas dan fungsionalitas dari sistem perpustakaan digital yang digunakan. Apakah sistem tersebut telah menjalankan fungsinya dengan baik? Dalam upaya menjalankan fungsi sebagai sebuah perpustakaan digital pengembang mengembangkaan beberapa menu I-Jogja. Beberapa menu tersebut antara lain.

a. Home

Menu home akan menampilkan daftar koleksi terbaru yang dimiliki I-Jogja. Dengan keberadaan menu ini memungkinkan masyarakat mengetahui koleksi terbaru yang dimiliki I-Jogja.

b. Profil Pengguna

Profil pengguna merupakan menu yang berisi beberapa info personal dari pemustaka IJogja. Beberapa informasi pemustaka yang ada pada menu ini antara lain berapa follower, berapa banyak pemustaka mengikuti pemustaka lain, catatan pemustaka, riwayat peminjaman, deskrisipi pemustaka dari antrian koleksi yang akan dipinjam oleh pustaka.

c. Kategori Buku

Kategori buku berisi koleksi yang dapat diunduh dan dipinjam dalam I-Jogja. Dalam setiap record buku, berisi informasi tentang judul, nama pengarang, cover buku untuk memberikan ilustrasi, jumlah pembaca e-book dan usulan dari pemustaka. Apabila pemustaka menekan tombol judul maka akan muncul fasilitas peminjaman, jumlah $e$ book yang tersedia, ukuran file dan deskripsi koleksi.

d. Kategori ePustaka

EPustaka berisi tentang publikasi yang dihasilkan oleh masyarakat dan Pemerintah Provinsi Daerah Istimewa Yogyakarta. Pemustaka atau masyarakat Yogyakarta dapat meminjam, mengunduh dan membaca publikasi yang dihasilkan masyarakat dan Pemintah Daerah Yogyakarta. Masyarakat yang terdaftar pada portal I-Jogja dapat juga meminjam e-book tersebut.

e. Peminjaman buku 
Peminjaman buku merupakan buku yang dianalogikakan sebagai rak buku, setelah mengunduh buku yang dipinjam maka buku tersebut aka muncul dalam daftar peminjaman buku. Pemustaka dapat dengan bebas membaca buku yang telah diunduh melalui menu ini. Sebagai sebuah sistem perpustakaan digital, I-Jogja telah menjalankan fungsinya dengan baik. Semua menu atau fasilitas yang ada di dalam IJogja telah berjalan sesuai dengan fungsinya.

6. Arsitektur

Komponen arsitektur mencerminkan perangkat lunak dan perangkat keras yang dibutuhkan dalam mewujudkan perpustakaan digital. Kebutuhan perangkat lunak dan keras yang perlu dipersiapkan sehingga masyarakat dapat mengakses koleksi digital yang tersimpan di dalam IJogja dipengaruhi dimana I-Jogja akan diinstalasi, apakah I-Jogja akan diinstalasi pada smartphone atau personal computer.

Apabila I-Jogja yang akan diinstalasi pada smartphone maka masyarakat perlu memperhatikan sistem operasi yang digunakan. Apakah smartphone menggunakan sistem operasi Android atau iOS yang biasa digunakan di smartphone I-Phone. Jika pemustaka ingin melakukan instalasi pada smartphone dengan sistem operasi Android maka kebutuhan yang perlu disiapkan antara lain:

1. Smartphone menggunakan sistem Android 4.0 atau diatasnya

2. Smartphone menggunakan minimal RAM 1 Gigabyte

3. Smartphone menggunakan layar minimal 4 inci

Untuk kebutuhan instalasi pada smartphone dengan sistem operasi iOS, kebutuhan yang perlu dipersiapkan antara lain:

1. Smartphone dengan iOS minimal 7 atau diatasnya

2. I-Jogja akan lebih bekerja masimal di smartphone I-Phone 5

3. Sesuai dengan I-Phone atau Ipad dengan teknologi layar sentuh.

Masyarakat juga dapat mengakses koleksi digital yang tersimpan di I-Jogja dengan melakukan instalasi pada personal computer. Personal computer tersebut minimal menggunakan sistem operasi Windows 7 dan menggunakan RAM minimal 1 Gigabyte. Saat ini masyarakat populer mengunakan sistem operasi Windows 8 dan 10. Dengan demikian, peluang untuk melakukan instalasi I-Jogja semakin mudah dilakukan. Jika berbagai kebutuhan perangkat lunak dan perangkat keras tersebut di atas dipenuhi maka komponen arsitektur akan berjalan dengan optimal. Pemustaka dapat mengunduh dan meminjam buku yang disediakan I-Jogja.

\section{KESIMPULAN}

Dari pembahasan yang telah dilakukan di atas maka penulis memperoleh berbagai kesimpulan yaitu:

1. Konten I-Jogja merupakan koleksi digital berbasis teks

I-Jogja menghimpun koleksi dalam format PDF. Jenis file ini termasuk kedalam ragam koleksi digital berbasis teks. Koleksi digital dalam format PDF tersebut merupakan buku elektronik dari berbagai penerbit yang dihimpun oleh pengembang I-Jogja.

2. Pengguna I-Jogja adalah masyarakat yang telah mendaftarkan diri kedalam aplikasi I-Jogja Pengguna I-Jogja adalah masyarakat Yogyakarta dan masyarakat daerah lain. Untuk dapat mengakses masyarakat harus mendaftarkan diri kedalam aplikasi I-Jogja.

3. I-Jogja berusaha menjalankan fungsi sebagai sarana pembinaan minat baca I-Jogja memiliki fungsi sebagai sarana pembinaan minat baca bagi masyarakat Yogyakarta. Untuk dapat menjalankan fungsi tersebut, semua fasilitas yang disedikan oleh I-Jogja telah 
berjalan sesuai dengan fungsinya. Semua fasilitas yang ada didalam I-Jogja telah berfungsi secara maksimal. Dengan berfungsinya fasilitas secara maksimal, memungkinkan masyarakat membaca berbagai koleksi digital yang ada didalam I-Jogja sehingga dapat merangsang minat baca masyarakat.

4. Kebijakan pengelolaan I-Jogja meliputi keanggotaan dan pola akses koleksi digital Koleksi digital yang ada didalam I-Jogja hanya dapat diakses oleh mereka yang telah terdaftar didalam aplikasi I-Jogja. Pengguna yang telah terdaftar dapat mengakses koleksi digital dengan cara membaca secara langsung melalui aplikasi dengan terlebih dahulu melakukan proses peminjaman. Konsep peminjaman ini dikenal dengan konsep e-leanding dan konsep ini merupakan pola akses baru dalam pengelolaan perpustakaan digital di Indonesia

5. I-Jogja memiliki kualitas yang baik kerena semua fasilitas telah berjalan sesuai dengan fungsinya. Untuk menjalankan fungsinya sebagai salah satu sarana pembinaan minat baca, tentu menuntut semua menu yang ada didalam I-Jogja berjalan dengan sempurna. Menu pendaftaran anggota, pencarian dan peminjaman yang ada didalam I-Jogja mampu berjalan sesuai dengan fungsinya.

6. Arsitektur I-Jogja memberikan kemungkinan bahwa aplikasi ini dapat berjalan pada sistem operasi iOS dan Android. iOS dan Android merupakan dua sistem operasi yang populer digunakan oleh smartphone di Indonesia. Dengan mampu berjalan di dua sistem operasi tersebut semakin banyak masyarakat yang dapat menggunakan I-Jogja sehingga dapat mengakses koleksi digital yang tersimpan didalamnya.

\section{DAFTAR PUSTAKA}

Authors, F. (2008). Digital rights description as part of digital rights management : a challenge for libraries. https://doi.org/10.1108/07378830810920923

Cleveland, G. (2008). Digital libraries: definitions, issues and challenges. Occasional Paper, IFLA UDT Core Program, 4(8), 1-10. Retrieved from http://www.ifla.org/udt/op/

Chowdhury, G.G. dan Chowdhury S. (2003). Introduction to Digital Libraries. Facet Publishing, London.

Isah, A., Mutshewa, A., Serema, B. C., \& Kenosi, L. (2013). Digital Libraries: Analysis of Delos Reference Model and 5S Theory. Journal of Information Science Theory and Practice, 1(4), 38-47. https://doi.org/10.1633/jistap.2013.1.4.

Ratna, N. K. (2016). Metode Penelitian Kajian Budaya dan Ilmu Sosial Humaniora pada Umumnya. Yogyakarta, Pustaka Pelajar

Seadle, M., \& Greifeneder, E. (2007). Defining a digital library. Library Hi Tech, 25(2), 169-173. https://doi.org/10.1108/07378830710754938

Sugiono. (2012). Metode Penelitian Kuantitatif, Kualitatif dan R\&D. Bandung, Alfabet.

Zhu, Q. (2002). 5SGraph : A Modeling Tool for Digital Libraries. 